\title{
Optimal Conditions for the Post-Harvest Storage of Rhizoids of the Brown Seaweed Undaria pinnatifida (Phaeophyta) for Arachidonic Acid Production
}

\author{
Mohammed Nurul Absar Khan ${ }^{1,2}$, Ji-Young Kang ${ }^{1}$, Nam Gyu Park ${ }^{1}$, Jae-Suk Choi ${ }^{3}$, In Soon Choi ${ }^{3,4}$, \\ Yong-Ki Hong ${ }^{1 *}$ \\ ${ }^{1}$ Department of Biotechnology, Pukyong National University, Busan 608-737, Korea \\ ${ }^{2}$ Department of Fisheries Technology, Bangladesh Agricultural University, Mymensingh-2202, Bangladesh \\ ${ }^{3}$ RIS Center, IACF, Silla University, Busan 617-736, Korea \\ ${ }^{4}$ Department of Biological Science, Silla University, Busan 617-736, Korea
}

\begin{abstract}
The non-utilized biomass of the aquacultured seaweed Undaria pinnatifida, particularly the rhizoid, is an alternative source of arachidonic acid (AA). Of the five aquacultured kelps that were tested, U. pinnatifida yielded the highest amount of AA, which was isolated from the rhizoids. Its identity (C20:4 n-6) was confirmed from gas chromatography-mass spectrometry spectral data. The optimal conditions for post-harvest storage or pretreatment of the rhizoids in Provasoli's enriched seawater for AA extraction were determined to be $\mathrm{pH} 7.8,2 \% \mathrm{CO}_{2}$-enriched air, $20 \mu \mathrm{mol} \mathrm{m} \mathrm{m}^{-2} \mathrm{~s}^{-1}$ light, and $10^{\circ} \mathrm{C}$. Under these conditions, the AA content after 1 day of storage was enhanced by up to $127 \%$. In the absence of light under ambient aeration, the AA content after 1 day of storage diminished to $90 \%$. Rhizoids collected late in the season (April and May) contained the highest amounts of AA (approximately $2.5 \mathrm{mg} / \mathrm{g}$ tissue).
\end{abstract}

Key words: Undaria pinnatifida, Arachidonic acid, Brown seaweed, Post-harvest, Rhizoid

\section{Introduction}

Arachidonic acid (AA) is one of the most abundant essential polyunsaturated fatty acids (PUFAs) in animal tissues, and it plays a significant role as a structural lipid predominantly associated with phospholipids (de Urquiza et al., 2000). AA is also the principal n-6 fatty acid in the brain; together with n-3 PUFAs, it plays an important role in the development of the infant brain (Hamosh and Salem, 1998). A strong relationship has been reported between the AA level in plasma and firstyear growth in preterm infants (Carlson et al., 1993). During early infancy, the nutritional requirement for AA must be met to achieve optimal growth. Thus, the blood concentration of AA correlates positively with birth weight in preterm infants
(Koletzko and Braun, 1991). According to Koletzko et al. (1996), AA is essential for normal visual acuity and cognitive development in infants after birth. AA is a component of human milk, and therefore, is a potentially valuable ingredient in various formulations of artificial baby food (Koletzko et al., 1989). It also plays an important role as a precursor of biologically active prostaglandins and leukotrienes, with important functions in the circulatory (Singh and Chandra, 1988) and central nervous systems (Innis, 1991). In adults, altered metabolism of AA may be associated with neurological disorders such as Alzheimer's disease and bipolar disorder (Rapoport, 2008). Dietary supplementation with AA during
Open Access http://dx.doi.org/10.5657/FAS.2012.0163

This is an Open Access article distributed under the terms of the Creative Commons Attribution Non-Commercial License (http://creativecommons. org/licenses/by-nc/3.0/) which permits unrestricted non-commercial use, distribution, and reproduction in any medium, provided the original work is properly cited.
Received 13 April 2012; Revised 7 May 2012

Accepted 21 May 2012

*Corresponding Author

E-mail: ykhong@pknu.ac.kr 
the early stage of Alzheimer's disease is effective at reducing symptoms and slowing the progression of the disease (Schaeffer et al., 2009).

Conventional sources of AA, including animal liver, fish oil, and egg yolk, contain approximately $0.2 \%$ (w/w) AA (Gill and Valivety, 1997). A current source of commercial AA is the fungus Mortierella alpina, in which the AA content can be as high as $7.7 \mathrm{~g} / \mathrm{L}$ culture (Zhu et al., 2006). Several algal species that contain AA have also been examined, including the red microalga Porphyridium cruentum (Ahern et al., 1983), some diatoms (Dunstan et al., 1994), the green microalga Tetraselmis suecica (Servel et al., 1994), and the brown seaweed Fucus (Kim et al., 1996).

Thalli of the brown seaweed Undaria pinnatifida are a popular health food in East Asia. The amount of U. pinnatifida produced by aquaculture in 2009 was $309,000 \mathrm{t}$ (wet weight), and an additional 4,000 $\mathrm{t}$ (wet weight) was collected from natural populations (Korea Fisheries Association, 2010). The rhizoid of $U$. pinnatifida is not used and is therefore discarded on land or at aquaculture farms. The decaying tissue is malodorous and pollutes the disposal area; thus, an economical use for this immense aquaculture biomass would reduce pollution. Previously, we reported that the $U$. pinnatifida rhizoid could be used as a source of AA (Khan et al., 2007). In this study, we determined the optimal conditions, including the percentage of $\mathrm{CO}_{2}$ in the air, light intensity, temperature, $\mathrm{pH}$, and drying and harvesting conditions, that maximize the amount of AA in $U$. pinnatifida rhizoids.

\section{Materials and Methods}

\section{Seaweed material and culture conditions}

The brown seaweed $U$. pinnatifida (Harvey) Suringar was collected from the Kijang aquaculture farm, Korea, during December 2010 and May 2011. Voucher specimens were deposited in our laboratory (Y.K. Hong). The middle of the rhizoid, which is used for AA production, was cut into 1-cm-long pieces, which were kept in filtered seawater at $10^{\circ} \mathrm{C}$ until use. A series of $250 \mathrm{~mL}$ beakers, each containing 15 pieces of rhizoid in $100 \mathrm{~mL}$ Provasoli's enriched seawater (PES) medium (Provasoli, 1968) were incubated for 1 day under standard

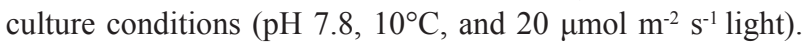
Light was provided by cool-white fluorescent lamps and was measured with a photometer (Sekonic Lumimeter 246; Tokyo, Japan). The $\mathrm{pH}$ was adjusted using $50 \mathrm{mM}$ Tris-Cl buffer in PES medium. Compressed air was supplied to the beakers, each with a different percentage of $\mathrm{CO}_{2}$, at a flow rate of 0.5 $\mathrm{L} \min ^{-1} \mathrm{~L}^{-1}$ medium. The $\mathrm{CO}_{2}$ was supplied for 1 day at $10^{\circ} \mathrm{C}$. The effects of the storage conditions on the amount of AA were measured using rhizoids collected in January 2011.

\section{Isolation and quantification of AA}

The rhizoids were removed from the beakers and dried in a vacuum freeze dryer (SFDSM 24L; Samwon Freezing Engineering Co., Busan, Korea). Each freeze-dried sample containing 15 pieces of rhizoid (approximately $0.4 \mathrm{~g}$ ) was ground with a mortar and pestle and poured into a $10 \mathrm{~mL}$ Teflon tube with a Tefzel cap. Extraction was conducted using $8 \mathrm{~mL}$ dichloromethane in a rotator for $24 \mathrm{~h}$ at $6 \mathrm{rpm}$. After centrifugation at 2,000 $\mathrm{g}$ for $5 \mathrm{~min}, 4 \mathrm{~mL}$ of the clean supernatant was collected and dried under a stream of nitrogen gas. Then the extract was dissolved in methanol $(5 \mathrm{mg} / \mathrm{mL})$ for analysis by reversed-phase high-pressure liquid chromatography (RPHPLC). Each $100 \mu \mathrm{L}$ aliquot was separated on a C18 column $(10 \mathrm{~mm}$ i.d. $\times 25 \mathrm{~cm})$ (Ultrasphere; Beckman Coulter, Fullerton, CA, USA). The analysis was performed on a Waters 600 gradient liquid chromatograph (Waters, Milford, MA, USA) that was monitored at $213 \mathrm{~nm}$. The mobile phase consisted of two solvent systems: acetonitrile with $0.1 \%$ trifluoroacetic acid (TFA) and distilled water with $0.1 \%$ TFA. The elution was performed using a linear gradient of 0 to $100 \% \mathrm{v} / \mathrm{v}$ acetonitrile over $30 \mathrm{~min}$ and with isocratic $100 \% \mathrm{v} / \mathrm{v}$ acetonitrile for an additional $10 \mathrm{~min}$, at a flow rate of $3 \mathrm{~mL} / \mathrm{min}$. AA was eluted at $34.6 \mathrm{~min}$ on $100 \%$ acetonitrile. The amount of AA was calculated from the dimensions of the HPLC peak using a standard curve produced from pure AA (A2581; Sigma, St. Louis, MO, USA).

\section{Analytical methods}

The isolated compound was analyzed by the gas chromatography-mass spectrometry (GC-MS, model GCMS-QP5050A; Shimadzu, Kyoto, Japan) equipped with a flame ionization detector, and the spectral data were compared to the manufacturer-supplied database. Electron ionization mass spectrometry (EIMS) and high resolution fast atom bombardment mass spectrometry (HR-FABMS) data were obtained from a JMS-700 spectrometer (JEOL, Tokyo, Japan) and a JMS HX 110 Tandem mass spectrometer (JEOL), respectively. The 1-D $\left({ }^{1} \mathrm{H},{ }^{13} \mathrm{C}\right.$, and DEPT) and 2-D (heteronuclear multiple quantum correlation [HMQC], heteronuclear multiple-bond correlation [HMBC], and correlation spectroscopy [COSY]) NMR spectra were measured using a JNM-ECP 400 NMR spectrometer (JEOL) with methanol- $d\left(\mathrm{CD}_{3} \mathrm{OD}\right)$ as the solvent. The structure of the compound was identified and confirmed to be identical to the spectral data for AA (Fu et al., 2004).

\section{Statistical analysis}

The experiments were replicated at least five times for each independent assay, and the highest and lowest values were discarded. The mean values of the indices were compared to the control using Student's $t$-tests. 


\section{Results}

\section{Identification of AA}

AA was eluted from the RP-HPLC column with $100 \%$ acetonitrile (at $34.6 \mathrm{~min}$ ) as an oily compound. GC-MS led to a tentative identification as alkenoic acid using the library that was supplied with the GC-MS. The compound was $>90 \%$ similar to eicosa-tetraenoic acid. The molecular composition was $\mathrm{C}_{20} \mathrm{H}_{32} \mathrm{O}_{2}$, as determined by HR-FABMS (negative mode, $[\mathrm{M}$ - $\mathrm{H}^{-}$at $\mathrm{m} / \mathrm{z} 303.2324$ ). These data indicate that the compound contained four carbon-carbon double bonds and one carbonyl carbon. From the assigned NMR data, the ${ }^{13} \mathrm{C}$-NMR spectrum revealed one carbonyl carbon $(\mathrm{C}-1)$, one methyl carbon at $\delta \mathrm{C}$ 14.8 (C-20), eight methylene carbons, and eight methane carbons. With the complementary ${ }^{13} \mathrm{C}-\mathrm{NMR}$ spectrum, the $1 \mathrm{H}$ NMR spectrum revealed the presence of a methyl proton at $\delta \mathrm{H}$ 0.83 (H-20), ten methylene protons, and eight methine proton signals. Assignments were made using COSY, HMQC, and HMBC spectra. From the COSY and HMBC spectra, the first double-bond position from the terminal methyl carbon (C-20) was determined. The terminal methyl proton $(\mathrm{H}-20)$ showed a COSY correlation to $\mathrm{H}-19$ and an HMBC correlation to C-18, and the proton $\mathrm{H}-18$ showed a HMBC correlation to $\mathrm{C}-17$. This fragment was extended by COSY correlations of two methylene protons $(\mathrm{H}-17, \mathrm{H}-16)$ and a methine proton $(\mathrm{H}-15)$, demonstrating that the first double bond was at the sixth position. From these spectral data, the compound was identified as eicosa-5,8,11,14-tetraenoic acid (C20:4 n-6), or AA.

\section{Comparison of the amount of AA in different sea- weed rhizoids}

We examined the amount of AA in rhizoids of five aquacultured kelp species (Costaria costata, Laminaria japonica, Sargassum fulvellum, Sargassum horneri, and U. pinnatifida). Among these species, $U$. pinnatifida yielded the largest amount of AA $(1,778 \mu \mathrm{g} / \mathrm{g})$, with levels being almost 50 -fold greater than in L. japonica specimens that were cultured at the same farm (Table 1).

Table 1. Comparison of the arachidonic acid (AA) content in rhizoids of different species of seaweeds ${ }^{*}$

\begin{tabular}{lc}
\hline \multicolumn{1}{c}{ Species } & Amount of AA $(\boldsymbol{\mu g} / \mathbf{g}$-tissue) \\
\hline Costaria costata & $287 \pm 11$ \\
Laminaria japonica & $36 \pm 2$ \\
Sargassum fulvellum & $478 \pm 30$ \\
Sargassum horneri & $64 \pm 6$ \\
Undaria pinnatifida & $1,778 \pm 19$
\end{tabular}

"The data are the mean weight \pm SE $(n \geq 3)$ of arachidonic acid from $1 \mathrm{~g}$ (dry weight) of rhizoids.

\section{Influence of storage parameters on AA production}

The effects of storage parameters on AA production were measured using rhizoids collected in January 2011. To determine the optimal conditions for post-harvest storage for AA production from $U$. pinnatifida, rhizoid tissues were incubated under standard culture conditions with compressed air with different percentages $(0-5 \%)$ of $\mathrm{CO}_{2}$. The optimal $\mathrm{CO}_{2}$ concentration for AA production (1.9 mg/g tissue) was $2 \%$ (Fig. 1A). The amount of AA did not increase even after $48 \mathrm{~h}$ of $\mathrm{CO}_{2}$ exposure (data not shown). When ambient air was supplied using an aerator, the amount of AA was reduced to $1.5 \mathrm{mg} / \mathrm{g}$ tissue. To determine the optimal light intensity for AA production, tissues were illuminated at intensities ranging from 0 to $60 \mu \mathrm{mol} \mathrm{m} \mathrm{m}^{-2} \mathrm{~s}^{-1}$ in PES medium under standard culture conditions. The optimal light intensity for AA production (2.0 $\mathrm{mg} / \mathrm{g}$ tissue) was $20 \mu \mathrm{mol} \mathrm{m} \mathrm{m}^{-2} \mathrm{~s}^{-1}$ (Fig. 1B). In the absence of light, the amount of AA diminished to $1.5 \mathrm{mg} / \mathrm{g}$ tissue. To determine the optimal temperature for AA production, tissues were cultured under a wide range of temperatures, from $0^{\circ} \mathrm{C}$ to $30^{\circ} \mathrm{C}$, in PES medium under standard culture conditions. The optimal temperature for AA production $(2.1 \mathrm{mg} / \mathrm{g}$ tissue $)$ was $10^{\circ} \mathrm{C}$ (Fig. 1C). The amount of AA was within $90 \%$ of this value with temperatures from $5^{\circ} \mathrm{C}$ to $15^{\circ} \mathrm{C}$. To determine the optimal $\mathrm{pH}$ for AA production, tissues were maintained at different $\mathrm{pH}$ values in PES and seawater under standard culture conditions. The $\mathrm{pH}$ values of the PES medium and seawater were adjusted using $50 \mathrm{mM}$ Tris- $\mathrm{HCl}$ buffer. The optimal $\mathrm{pH}$ was 7.8 , with the amount of AA being 2.1 and $2.0 \mathrm{mg} / \mathrm{g}$ tissue in PES and seawater, respectively (Fig. 1D).

\section{Effects of drying conditions and harvest season on AA production}

We examined the effects of various storage and drying conditions on the amount of AA in $U$. pinnatifida rhizoids (Table 2). When stored in liquid nitrogen, at $-20^{\circ} \mathrm{C}$, or at $4^{\circ} \mathrm{C}$ for 1 week, the amount of AA produced was reduced compared to rhizoids subjected to direct lyophilization. Shadow-drying (69-84\%) and sun-drying (58-77\%) for 1 week reduced the AA content even further. With respect to harvest season, rhizoids collected late in the season had higher amounts of AA; the AA content was $2.5 \mathrm{mg} / \mathrm{g}$ tissue in $U$. pinnatifida rhizoids harvested in April and May, which was approximately 1.5-fold greater than in rhizoids harvested in December and January.

\section{Discussion}

We isolated n-6 PUFA AA from $U$. pinnatifida rhizoids, which are normally disposed of as waste, creating pollution on aquaculture farms. Edible $U$. pinnatifida thalli contained large amounts of eicosapentaenoic acid, stearidonic acid, and AA, which possess anti-inflammatory activities (Khan et al., 

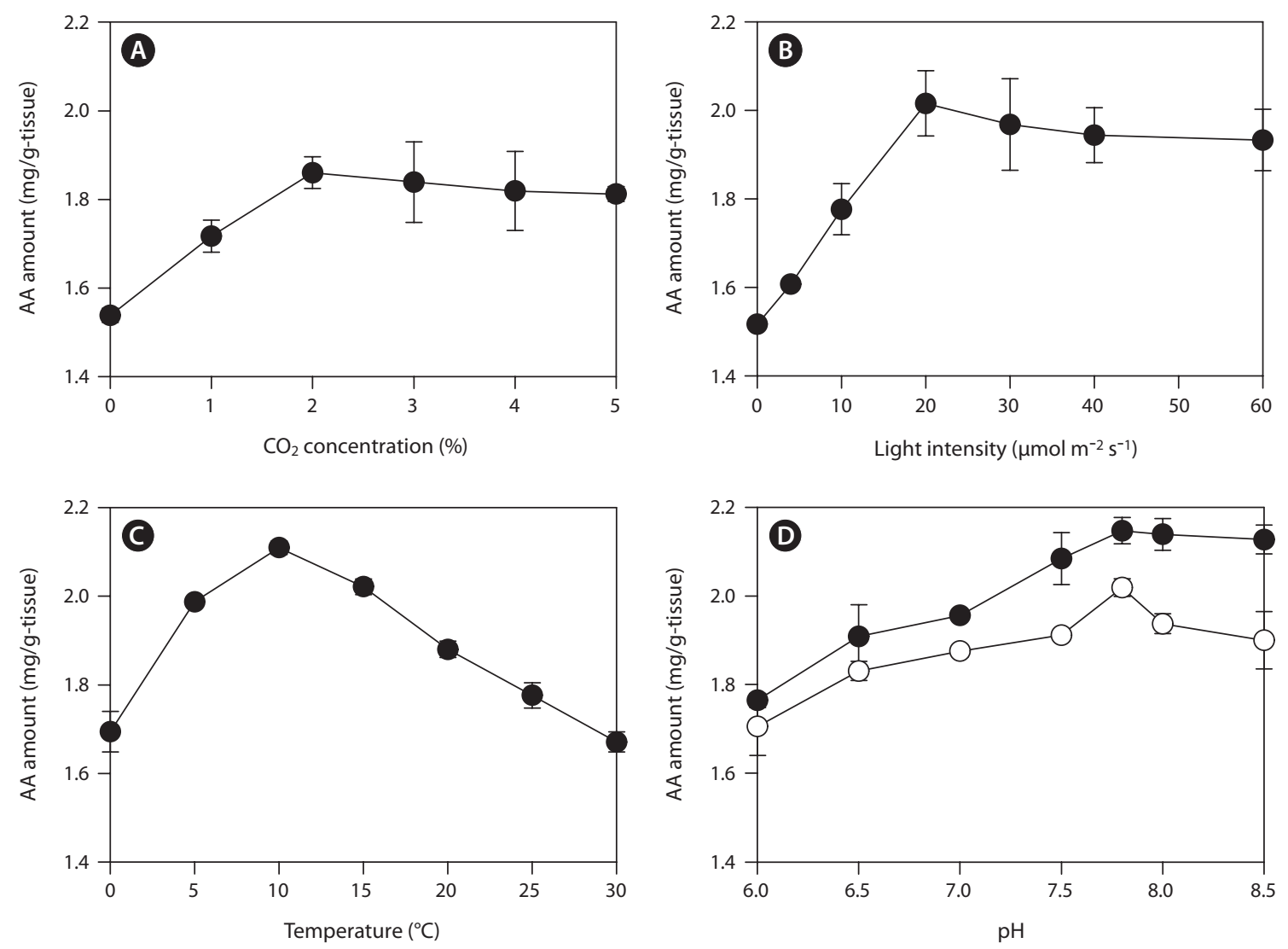

Fig. 1. Effects of storage parameters on arachidonic acid (AA) production in Undaria pinnatifida rhizoids. (A) Effect of $\mathrm{CO}_{2}$ supply on $\mathrm{AA}$ production. Compressed air mixed with $\mathrm{CO}_{2}$ was supplied to PESI medium at a flow rate of $0.5 \mathrm{~L} \mathrm{~min}^{-1} \mathrm{~L}^{-1}$ medium under standard culture conditions. (B) Effect of light intensity on AA production. Illumination was provided by cool-white fluorescent lamps under standard culture conditions. (C) Effect of temperature on AA production. The rhizomes were incubated at different temperatures for 1 day under standard culture conditions. (D) Effect of pH on AA production. The rhizomes were incubated in PESI medium (closed circle) or seawater (open circle) at various pH values for 1 day under standard culture conditions. The amount of $A A$ is expressed in $\mathrm{mg}$ and represents the mean weight $\pm \mathrm{SE}(n \geq 3)$ of AA from $1 \mathrm{~g}$ (dry weight) of rhizoids.

Table 2. Effects of the drying conditions and harvest season on the amount of arachidonic acid (AA) from rhizoids of Undaria pinnatifida*

\begin{tabular}{|c|c|c|c|}
\hline & $\begin{array}{c}\text { Amount of AA from } \\
\text { Dec-Jan }\end{array}$ & $\begin{array}{c}\text { Amount of AA from } \\
\text { Feb-Mar }\end{array}$ & $\begin{array}{c}\text { Amount of AA from } \\
\text { Apr-May }\end{array}$ \\
\hline Directly lyophilized tissues & $\begin{array}{c}1,674.4 \pm 23.9 \\
(100 \%)\end{array}$ & $\begin{array}{c}1,970.3 \pm 18.7 \\
(100 \%)\end{array}$ & $\begin{array}{c}2,498.9 \pm 16.6 \\
(100 \%)\end{array}$ \\
\hline Tissues stored in liquid $\mathrm{N}_{2}$ for 1 week and lyophilized & $\begin{array}{c}1,615.2 \pm 17.1 \\
(96 \%)\end{array}$ & $\begin{array}{c}1,902.3 \pm 25.9 \\
(97 \%)\end{array}$ & $\begin{array}{c}2,163.0 \pm 66.5 \\
(87 \%)\end{array}$ \\
\hline Tissues stored at $-20^{\circ} \mathrm{C}$ for 1 week and lyophilized & $\begin{array}{c}1,484.8 \pm 9.1 \\
(89 \%)\end{array}$ & $\begin{array}{c}1,748.7 \pm 19.3 \\
(89 \%)\end{array}$ & $\begin{array}{c}1,842.1 \pm 37.5 \\
(74 \%)\end{array}$ \\
\hline Tissues stored at $4^{\circ} \mathrm{C}$ for 1 week and lyophilized & $\begin{array}{c}1,461.5 \pm 14.3 \\
(87 \%)\end{array}$ & $\begin{array}{c}1,630.2 \pm 13.0 \\
(83 \%)\end{array}$ & $\begin{array}{c}1,780.6 \pm 12.4 \\
(71 \%)\end{array}$ \\
\hline Shadow-dried tissues & $\begin{array}{c}1,399.2 \pm 6.0 \\
(84 \%)\end{array}$ & $\begin{array}{c}1,618.3 \pm 30.2 \\
(82 \%)\end{array}$ & $\begin{array}{c}1,718.9 \pm 13.9 \\
(69 \%)\end{array}$ \\
\hline Sun-dried tissues & $\begin{array}{c}1,293.3 \pm 12.5 \\
(77 \%)\end{array}$ & $\begin{array}{c}1,341.5 \pm 11.2 \\
(68 \%)\end{array}$ & $\begin{array}{c}1,458.5 \pm 5.4 \\
(58 \%)\end{array}$ \\
\hline
\end{tabular}

"Samples of shadow- and sun-dried tissues were dried for 1 week using an electric fan. The data are expressed in $\mu \mathrm{g}$ and represent the mean weight $\pm \mathrm{SE}$ $(n \geq 3)$ of arachidonic acid from $1 \mathrm{~g}$ (dry weight) of rhizoids. Relative amounts (\%) are expressed against the amount of AA in the directly lyophilized rhizoids. 
2007). Holdfasts from mature and young $U$. pinnatifida contained 2.6- and 1.7-fold more AA than blade parts. Usually, when algal growth is slowed under conditions of stress, including intense light or nitrogen deficiency, the biosynthesis of lipids is enhanced at the expense of proteins and carbohydrates (Merzlyak et al., 2006). Although the rhizoids were not actively growing during the short (1 day) storage time in this study, it is conceivable that they can produce and maintain AA maximally under optimal storage conditions. Ahern et al. (1983) reported that increases in light intensity led to increased AA production in the red microalga P. cruentum, whereas temperature had an inverse effect on AA production. Similarly, our findings showed that maximal AA levels were obtained at higher light intensities and lower temperatures. A $5 \% \mathrm{CO}_{2}$-enriched air supply also increased AA production in P. cruentum (Akimoto et al., 1998). Our results also showed increased AA production when $2 \%$ or higher $\mathrm{CO}_{2}$-enriched air was supplied to $U$. pinnatifida rhizoids.

AA is an essential fatty acid in human nutrition and is a biogenetic precursor of several key eicosanoid hormones, including prostaglandins, thromboxanes, leukotrienes, and other pharmacologically active metabolites (Singh and Chandra, 1988). In addition, AA comprises about $0.3-0.7 \%$ of the total fatty acid content in human milk (Yuhas et al., 2006). The Food and Agriculture Organization (FAO) of the United Nations recommends supplementing infant formula with AA (FAO, 2010). The requirement in the adult brain showed approximately $18 \mathrm{mg} \mathrm{AA}$ /day as a free fatty acid in the plasma compartment (FAO, 2010). AA also activates the growth and repair of neurons (Darios and Davletov, 2006). Thus, there has been increasing interest in the production of AA because of its applicability to such fields as medicine, pharmacology, cosmetics, the food industry, and agriculture. A current commercial source of AA is the fungus $M$. alpina (Zhu et al., 2006). Other conventional commercial sources of AA generally contain approximately $0.2 \%(\mathrm{w} / \mathrm{w})$ AA (Gill and Valivety, 1997). This study showed that $U$. pinnatifida rhizoids produced $0.25 \%(\mathrm{w} / \mathrm{w})$ AA during April and May. This seaweed is an abundant, culturable marine plant found along temperate coastal regions of the northwestern Pacific Rim, including Korea, Japan, and China. It also occurs in temperate regions worldwide as an invasive species (Aguilar-Rosas et al., 2004). Hence, the $U$. pinnatifida rhizoid is a promising alternative source of AA because of its huge biomass, potential for waste utilization, and its high AA content. In the future, we plan to identify the genes involved in the desaturation and elongation steps of AA synthesis in this seaweed.

\section{Acknowledgments}

This research was supported by a grant from the Busan Sea mustard Sea tangle Regional Strategic Food Industry Promotion Agency funded by MIFAFF, Korea. We thank the postdoc- toral fellowship from Pukyong National University (MNAK) and Brain Busan 21 program for graduate support (JYK).

\section{References}

Aguilar-Rosas R, Aguilar-Rosas LE, Ávila-Serrano G and MarcosRamírez R. 2004. First record of Undaria pinnatifida (Harvey) Suringar (Laminariales, Phaeophyta) on the Pacific coast of Mexico. Bot Mar 47, 255-258.

Ahern TJ, Katoh S and Sada E. 1983. Arachidonic acid production by red alga Porphyridium cruentum. Biotechnol Bioeng 25, 10571070.

Akimoto M, Shirai A, Ohtaguchi K and Koide K. 1998. Carbon-dioxide fixation and polyunsaturated fatty acid production by the red alga Porphyridium cruentum. Appl Biochem Biotechnol 73, 269-278.

Carlson SE, Werkman SH, Peeples JM, Cooke RJ and Tolley EA. 1993. Arachidonic acid status correlates with first year growth in preterm infants. Proc Natl Acad Sci U S A 90, 1073-1077.

Darios F and Davletov B. 2006. Omega-3 and omega-6 fatty acids stimulate cell membrane expansion by acting on syntaxin 3. Nature 440, 813-817.

de Urquiza AM, Liu S, Sjöberg M, Zetterstrom RH, Griffiths W, Sjövall J and Perlmann T. 2000. Docosahexaenoic acid, a ligand for the retinoid X receptor in mouse brain. Science 290, 2140-2144.

Dunstan GA, Volkman JK, Barrett SM, Leroi JM and Jeffrey SW. 1994. Essential polyunsaturated fatty acids from 14 species of diatom (Bacillariophyceae). Phytochemistry 35, 155-161.

Food and Agriculture Organization of the United Nations (FAO). 2010. Fats and Fatty Acids in Human Nutrition: Report of an Expert Consultation. FAO, Rome, IT.

Fu M, Koulman A, van Rijssel M, Lützen A, de Boer MK, Tyl MR and Liebezeit G. 2004. Chemical characterization of three haemolytic compounds from the microalgal species Fibrocapsa japonica (Raphidophyceae). Toxicon 43, 355-363.

Gill I and Valivety R. 1997. Polyunsaturated fatty acids, part 1: occurrence, biological activities and applications. Trends Biotechnol 15, 401-409.

Hamosh M and Salem N Jr. 1998. Long-chain polyunsaturated fatty acids. Biol Neonate 74, 106-120.

Innis SM. 1991. Essential fatty acids in growth and development. Prog Lipid Res 30, 39-103.

Khan MNA, Cho JY, Lee MC, Kang JY, Park NG, Fuji H and Hong YK. 2007. Isolation of two anti-inflammatory and one pro-inflammatory polyunsaturated fatty acids from the brown seaweed Undaria pinnatifida. J Agric Food Chem 55, 6984-6988.

Kim MK, Dubacq JP, Thomas JC and Giraud G. 1996. Seasonal variations of triacylglycerols and fatty acids in Fucus serratus. Phytochemistry 43, 49-55.

Koletzko B and Braun M. 1991. Arachidonic acid and early human growth: is there any relation? Ann Nutr Metab 35, 128-131.

Koletzko B, Schmidt E, Bremer HJ, Haug M and Harzer G. 1989. Effects of dietary long-chain polyunsaturated fatty acids on the essential fatty acid status of premature infants. Eur J Pediatr 148, 
669-675.

Koletzko B, Decsi T and Demmelmair H. 1996. Arachidonic acid supply and metabolism in human infants born at full term. Lipids 31, 79-83.

Korea Fisheries Association. 2010. Korean Fisheries Yearbook. Korea Fisheries Association, Seoul, KR.

Merzlyak MN, Solovchenko AE, Chivkunova OB, Khozin-Goldberg I, Didi-Cohen S and Cohen Z. 2006. Effect of light and nitrogen availability on growth and accumulation of arachidonic acid in the microalgae Parietochloris incise. In: Industrial Application of Biotechnology. Krylov IA and Zaikov GE, eds. Nova Science Publishers, New York, US, pp. 9-16.

Provasoli L. 1968. Medium and prospects for the cultivation of marine algae. In: Cultures and Collections of Algae. Watanabe A and Hattori A, eds. Japanese Society of Plant Physiology, Tokyo, JP, pp. 63-75.
Rapoport SI. 2008. Arachidonic acid and the brain. J Nutr 138, 25152520 .

Schaeffer EL, Forlenza OV and Gattaz WF. 2009. Phospholipase $\mathrm{A}_{2}$ activation as a therapeutic approach for cognitive enhancement in early-stage Alzheimer disease. Psychopharmacology (Berl) 202, 37-51.

Servel MO, Claire C, Derrien A, Coiffard L and de Roeck-Holtzhayer Y. 1994. Fatty acid composition of some marine microalgae. Phytochemistry 36, 691-693.

Singh G and Chandra RK. 1988. Biochemical and cellular effects of fish and fish oils. Prog Food Nutr Sci 12, 371-419.

Yuhas R, Pramuk K and Lien EL. 2006. Human milk fatty acid composition from nine countries varies most in DHA. Lipids 41, 851-858.

Zhu M, Yu LJ, Li W, Zhou PP and Li CY. 2006. Optimization of arachidonic acid production by fed-batch culture of Mortierella alpina based on dynamic analysis. Enzyme Microb Technol 38, 735-740. 